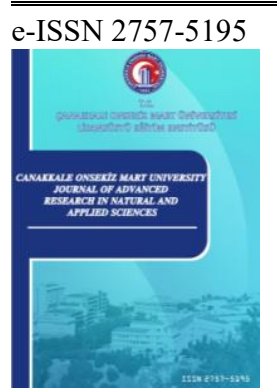

Çanakkale Onsekiz Mart University

Journal of Advanced Research in Natural and Applied Sciences

Open Access

doi.org/10.28979/jarnas. 939582

2021, Vol. 7, Issue 4, Pages: 556-569

dergipark.org.tr/tr/pub/jarnas

\title{
Evaluation of The Use R450A as an Alternative to R134a in Low and Medium Temperature Heat Pump Systems: 4-E (Energy, Exergy, Environmental and Enviro-Economic) Analysis
}

\author{
Ragıp Yıldırım ${ }^{1 *}$ \\ ${ }^{1}$ Department of Electricity and Energy, Bucak Emin Gulmez Vocational School of Technical Sciences, Burdur Mehmet Akif Ersoy \\ University, Burdur, Turkey
}

\begin{abstract}
Article History
Received: $\quad 19.05 .2021$

Accepted: $\quad 09.09 .2021$

Published: $\quad 15.12 .2021$
\end{abstract}

Research Article

\begin{abstract}
This investigation presents a theoretical evaluation of the use R450A replace to R134a in the low and medium temperature heat pump systems. The energy, exergy, environmental and enviro-economic analyzes of heat pumps have been performed for two refrigerants (R134a and its alternative R450A). The thermodynamic and environmental analyses have been made for two heat source temperatures $\left(10{ }^{\circ} \mathrm{C}\right.$ and $\left.20{ }^{\circ} \mathrm{C}\right)$ and six heat sink temperatures (from $30^{\circ} \mathrm{C}$ to $55^{\circ} \mathrm{C}$ ). It has been observed that R450A's mass flow rate is lower than R134a. Because the density of R450A in the heat pump suction line is lower than R134a. Although the heating capacity of R134a is more than R450A, the reason why R134a has a similar COP value with R450A is that R450A's compressor energy consumption is lower than R134a. Exergy destruction occurred mostly in the compressor under all operating conditions for both refrigerants. At low heat sink temperatures, minimum exergy destruction occurs in the expansion valve, as the minimum exergy destruction occurs in the evaporator at high heat sink temperatures. The exergy results show that R450A behaves similarly to R134a. In conclusion, as alternative refrigerant R450A can be used in heat pumps replace to R134a according to energy, exergy, environmental and environmental-economic analysis results.
\end{abstract}

Keywords - Climate change, energy and exergy, global warming, heat pump, new generating refrigerants

\section{Introduction}

Heat pump is known as an effective method to generate high-temperature heat energy. Heat pump absorbs heat from many sources such as air, soil and industrial waste and it supplies hot water (Jiang et al., 2021; Mateu-Royo et al., 2021). The raising of heat pump output temperature affects the usage areas of the heat pump system. Therefore, a heat pump is replacing a conventional building or industrial boilers (coal and oil burning boiler, flammable gas boiler, electrical heater, and so on) (Zhang et al., 2016).The schematic of air and ground (geothermal) source heat pump for low and medium temperature warming applications is seen in Figure 1.

\footnotetext{
1 (D) ryildirim@mehmetakif.edu.tr

${ }^{*}$ Corresponding Author
} 


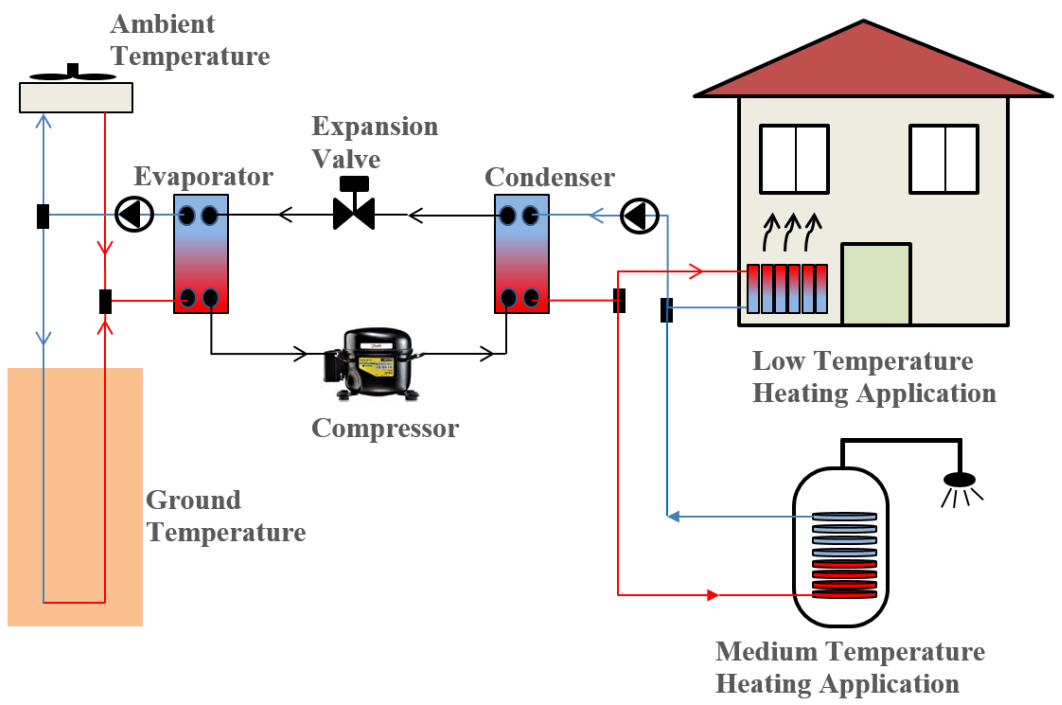

Figure 1. Schematic of the air and ground (geothermal) source heat pump system for low and medium temperature heating applications

The refrigerants used in heat pumps and operating temperatures significantly affect the efficiency (COP) of heat pumps. For this reason, it is significant to choose suitable refrigerants to achieve high efficiency under desired operating conditions (Yang et al., 2021). Calm has examined the development of refrigerants since 1830 in four categories (Figure 2). The refrigerants used in vapor compression systems reason environmental pollution, depleting the ozone layer and cause global warming. Many legal regulations have been made to diminish the effect of refrigerants on the environment. In addition, with Montreal Protocol's Kigali Amendment on January 1, 2019, coming into force, strict requirements have been imposed for refrigerants. For example, HFCs (Hydrofluorocarbons) have been included in organized schedules (Arora et al., 2018; Calm, 2008; Ciconkov, 2018; Heredia-Aricapa et al., 2020; Yang et al., 2021). These days, researchers have been seeking alternative refrigerants which have low global warming potential (GWP) and zero ozone depletion potential (ODP) to deal with global warming.

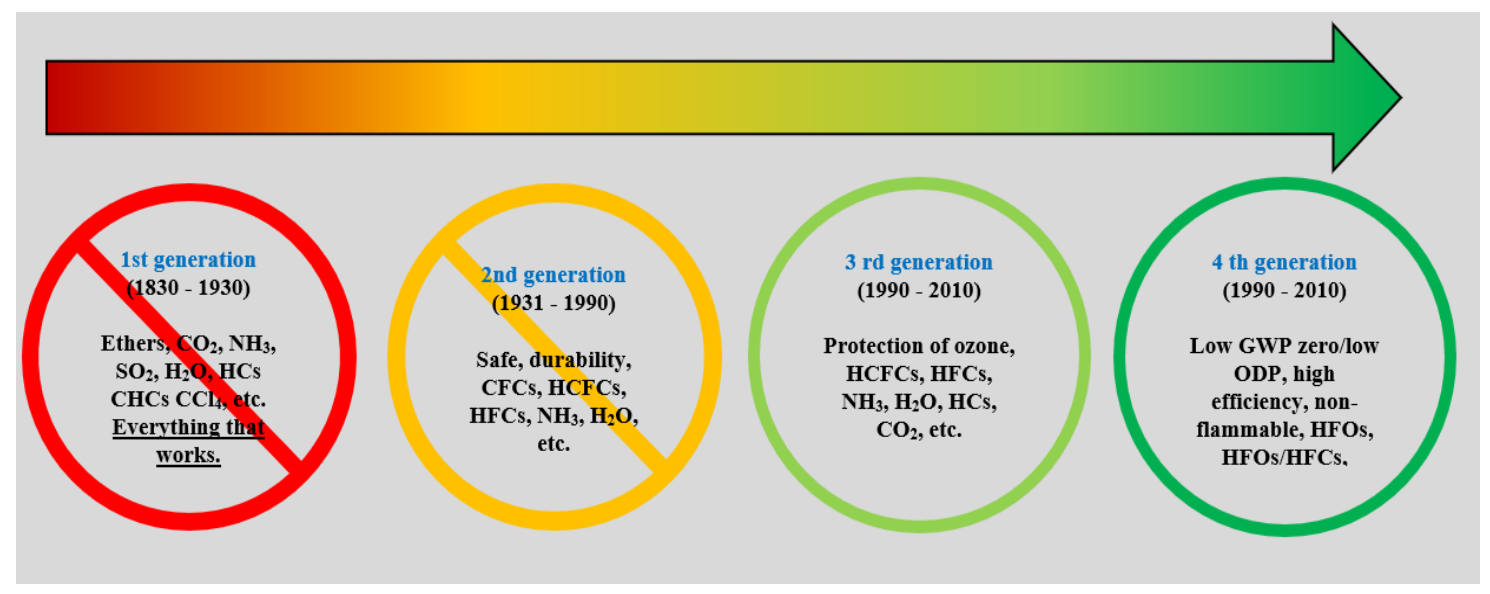

Figure 2. Progression of refrigerants development since 1830 (Calm, 2008)

R1234yf and R1234ze refrigerants in the hydrofluorofins (HFOs) group are the first synthetic refrigerants with a low GWP rate developed to replace R134a. R1234yf and R1234ze have low GWP (smaller than 1) and low flammability. The advantages and disadvantages of these fluids were examined in a lot of theoretical and experimental studies. R1234yf does not enhance the cooling capacity and modifications are necessary to use R1234ze (Yildirim \& Yildiz, 2020a, 2020b; Zilio et al., 2011). HFC/HFO mixtures can eliminate some disadvantages of pure HFOs and improve their thermal properties. Recently, new generation refrigerants with low GWP refrigerants made of HFC/HFO binary mixture have been improved (R513A and R450A). 
R513A refrigerant made from mixing R134a/R1234yf binary mixture at a ratio of 44/56 percent by mass. The ODP of R513A refrigerant is zero and its GWP ratio is half that of R134a refrigerant. R450A refrigerant is another low GWP refrigerant mixture that can be used in place of R134a. R450A refrigerant consists of a combination of R1234ze (E)/R134a with a ratio of 58/42 percent by mass. Its global warming potential is 547. Similar to R134a, R513A and R450A refrigerants are non-toxic and non-flammable fluids and classified as non-flammable and non- toxic fluids (A1) by ASHRAE (Llopis et al., 2017; Velasco et al., 2021).

There are many studies within the literature on the utilization of HFC, HFO and HFC/ HFO binary mixtures in vapor compression systems. Llopis et al. (2017) experimentally examined 450A and R513A refrigerant as an alternative to R507A and R134a in a cooling system. They evaluated their experimental results concerning the system's compressor power consumption of 24 hours. They point out that the compressor consumption of R513A and R450A refrigerants is slightly above R134a, but they're directly effective in decrease greenhouse emission emissions. Devecioğlu \& Oruç, (2018) theoretically investigated the energy performances of R1234ze, R1234yf, R445A, R513A and R450A refrigerants, which are alternative to R134a refrigerant, which have low GWP values. For the energy and exergy analysis of refrigerants, they used three different vapor compression cycles: simple refrigeration cycle, simple refrigeration cycle has internal heat exchanger, and two-stage cascade refrigeration cycle. They explained that the COP value of R450A refrigerant is extremely almost like R134a refrigerant and R450A's GWP value is 58\% less than R134a. The highest COP value for all operating conditions and refrigerants was seen in the simple refrigeration cycle with an internal heat exchanger. The highest exergy efficiency for all three refrigeration cycles has been achieved when using the R445A refrigerant. Gatarić \& Lorbek (2021) have experimentally studied that using R450A as an alternative to R134a in a household heat pump tumble dryer. They explained that R450A can be used as a good alternative to R134a in heat pump tumble dryers. Gill et al., (2019) experimentally investigated the exergy analysis of vapor compression refrigeration system for R134a and R450A. They stated that the exergy destruction rate and exergy efficiency of the vapor compression system using R450A refrigerant was approximately $15.25 \%$ to $27.32 \%$ lower and $10.07 \%$ to $130.93 \%$ higher than R134a, respectively.

As seen in the literature studies given above, R450A refrigerant can be used instead of R134a. In addition, R450A significantly reduces the global warming potential. However, it has been observed that the studies in the literature generally focus on the energetic and exergetic analysis of the cooling system. There is no comprehensive study of the potential of these refrigerants for use in medium or high-temperature heat pump systems. In this paper, the use of R450A instead of R134a in low and medium-temperature heat pump systems was evaluated. The energy, exergy, environmental and enviro-economic analyzes of heat pump have been performed for R134a and its alternative R450A.

\section{Materials and Methods}

The single-stage heat pump system given in Figure 3 was used to evaluate the performance of R134a and R450A. While making theoretical calculations, some assumptions are made that can be applied to all refrigerants. Some of the assumptions made in this investigation are given in Table 1. The main properties of $\mathrm{R} 134 \mathrm{a}$ and R450A are presented in Table 2. 


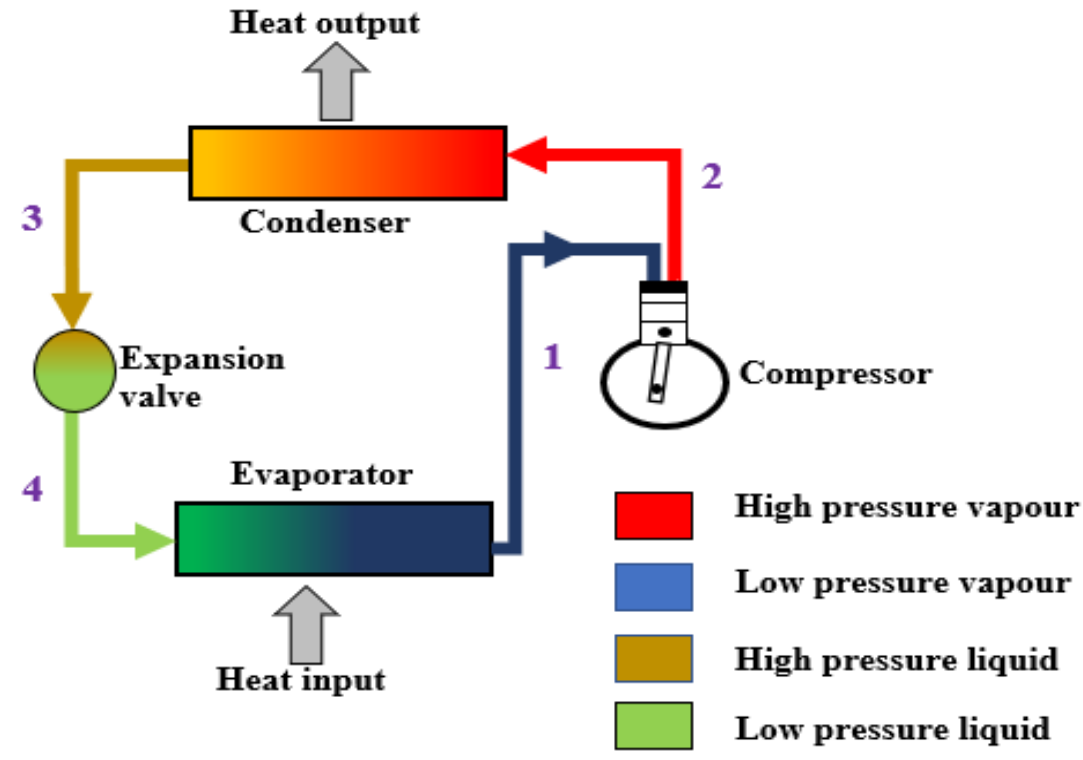

Figure 3. The schematic view of the heat pump

Table 1

Assumptions made for theoretical analysis

\begin{tabular}{ll}
\hline Heat sink temperature $\left(\mathrm{T}_{\text {heat,sink }}\right)$ & $30-55^{\circ} \mathrm{C}$ \\
\hline Heat source temperature $\left(\mathrm{T}_{\text {heat,source }}\right)$ & 10 and $20{ }^{\circ} \mathrm{C}$ \\
\hline Superheat temperature $\left(\Delta \mathrm{T}_{\text {superheat }}\right)$ & $5{ }^{\circ} \mathrm{C}$ \\
\hline Subcooling temperature $\left(\Delta \mathrm{T}_{\text {subcooling }}\right)$ & $5{ }^{\circ} \mathrm{C}$ \\
\hline The temperature difference between heat sink and condenser $\left(\Delta \mathrm{T}_{\text {heat,sink }}\right)$ & $10{ }^{\circ} \mathrm{C}$ \\
\hline The temperature difference between heat source and evaporator $\left(\Delta \mathrm{T}_{\text {heat,source }}\right)$ & $10{ }^{\circ} \mathrm{C}$ \\
\hline Compressor isentropic efficiency $(\eta)$ & 0.80 \\
\hline Compressor sweep volume & $26.11 \mathrm{~cm}^{3} / \mathrm{rev}$ \\
\hline
\end{tabular}

Table 2

The properties of R134a and R450A (Kumas \& Akyüz, 2020)

\begin{tabular}{lll}
\hline Refrigerants & R134a & R450A \\
\hline Composition & Pure & R134a/R1234ze $(\mathrm{E})(42 / 58$ in mass $)$ \\
\hline GWP & 1300 & 547 \\
\hline ODP & 0 & 0 \\
\hline Critical temperature $\left({ }^{\circ} \mathrm{C}\right)$ & 101.10 & 104.47 \\
\hline Critical pressure $(\mathrm{kPa})$ & 4059.30 & 3814.00 \\
\hline Boiling temperature $\left({ }^{\circ} \mathrm{C}\right)$ & -24.60 & -23.36 \\
\hline Liquid density $\left(\mathrm{kg} / \mathrm{m}^{3}\right)^{*}$ & 1295.30 & 1253.28 \\
\hline Vapor density $\left(\mathrm{kg} / \mathrm{m}^{3}\right)^{*}$ & 14.35 & 13.93 \\
\hline Liquid $\mathrm{c}_{\mathrm{p}}(\mathrm{kJ} / \mathrm{kg} \mathrm{K})^{*}$ & 1.34 & 1.32 \\
\hline Vapor $\mathrm{c}_{\mathrm{p}}(\mathrm{kJ} / \mathrm{kg} \mathrm{K})^{*}$ & 0.89 & 0.90 \\
\hline *at $0{ }^{\circ} \mathrm{C}$ & &
\end{tabular}




\subsection{Thermodynamics Analyses}

\subsubsection{Energy Analysis}

Energy analysis of the heat pump system has been performed in accordance with to the first law of thermodynamics. The necessary equations for the energy analysis of the heat pump system (Figure 3) are given below (Çengel \& Boles M. A., 2008; Chiasson, 2016; Dincer \& Kanoğlu, 2010):

The theoretical mass flow rate of refrigerant $\left(\dot{\mathrm{m}}_{\mathrm{ref}}\right)(\mathrm{kg} / \mathrm{s})$ is calculated by Equation 2.1 .

$\dot{\mathrm{m}}_{\text {ref }}=\rho_{\text {suction }} \dot{\mathrm{V}}_{\text {ref }}$

$\rho_{\text {suction }}$ indicates the refrigerant suction line density $\left(\mathrm{kg} / \mathrm{m}^{3}\right)$, and $\dot{\mathrm{V}}_{\text {ref }}$, indicates the refrigerant volume flow rate $\left(\mathrm{m}^{3} / \mathrm{kg}\right)$.

In the heat pump cycle, $\mathrm{s}_{1}$ and $\mathrm{s}_{2}$ indicate the specific entropy $(\mathrm{kJ} / \mathrm{kg} \mathrm{K})$ value at the compressor inlet and outlet, respectively. Therefore, within the case of isentropic compression, $s_{1}$ and $s_{2}$ is equal (Equation 2.2).

$\mathrm{s}_{1}=\mathrm{s}_{2 \mathrm{~s}}$

The ideal compressor energy consumption $\left(\dot{\mathrm{W}}_{\text {compressor,ideal }}\right)$ and the actual compressor energy consumption ( $\left.\dot{\mathrm{W}}_{\text {compressor,actual }}\right)$ can be calculated with Equation 2.3 and Equation 2.4.

$\dot{\mathrm{W}}_{\text {compressor,ideal }}=\dot{\mathrm{m}}_{\mathrm{ref}}\left(\mathrm{h}_{2 \mathrm{~s}}-\mathrm{h}_{1}\right)$

$\dot{\mathrm{W}}_{\text {compressor,actual }}=\dot{\mathrm{m}}_{\text {ref }}\left(\mathrm{h}_{2}-\mathrm{h}_{1}\right)$

Here, $h_{1}$ indicates the specific enthalpy $(\mathrm{kJ} / \mathrm{kg})$ value of the refrigerant at the compressor inlet, $\mathrm{h}_{2 \mathrm{~s}}$ indicates the specific enthalpy value $(\mathrm{kJ} / \mathrm{kg})$ at the compressor outlet as a result of isentropic compression. The specific enthalpy $(\mathrm{kJ} / \mathrm{kg})$ value $\left(\mathrm{h}_{2}\right)$ at the compressor output in the actual heat pump cycle can be calculated with Equation 2.5.

$\mathrm{h}_{2}=\mathrm{h}_{1}+\frac{\left(\mathrm{h}_{2 \mathrm{~s}}-\mathrm{h}_{1}\right)}{\mathrm{\eta}}$

$\eta$ indicates the compressor's isentropic efficiency. In the heat pump cycle, the heat released from the conden$\operatorname{ser}\left(\dot{\mathrm{Q}}_{\text {condenser }}\right)$ and the heat is taken from the evaporator $\left(\dot{\mathrm{Q}}_{\text {evaporator }}\right)$ can be calculated with Equation 2.6 and Equation 2.7.

$\dot{\mathrm{Q}}_{\text {condenser }}=\dot{\mathrm{m}}_{\mathrm{ref}}\left(\mathrm{h}_{2}-\mathrm{h}_{3}\right)$

$\dot{\mathrm{Q}}_{\text {evaporator }}=\dot{\mathrm{m}}_{\text {ref }}\left(\mathrm{h}_{1}-\mathrm{h}_{4}\right)$

The refrigerant's enthalpy value at the inlet and outlet of the expansion valve is that the same. Since, there is no work and heat inlet and outlet within the expansion valve (Equation 2.8).

$\mathrm{h}_{3}=\mathrm{h}_{4}$

$\mathrm{h}_{3}$ and $\mathrm{h}_{4}$ show the enthalpy value $(\mathrm{kJ} / \mathrm{kg})$ at the in and out of expansion valve, respectively. The heating COP (coefficient of performance) can be calculated with Equation 2.9. 
$\mathrm{COP}=\frac{\dot{\mathrm{Q}}_{\text {condenser }}}{\dot{\mathrm{W}}_{\text {compressor,actual }}}=\frac{\mathrm{h}_{2}-\mathrm{h}_{3}}{\mathrm{~h}_{2}-\mathrm{h}_{1}}$

\subsubsection{Exergy Analysis}

Exergy analysis of the heat pump system has been performed in accordance with to the second law of thermodynamics. The general exergy balance equation for steady flow and control volumes is given in Equation 2.10. In Equation 2.10, Ė $\mathrm{x}_{\mathrm{d}}$ indicates exergy destruction rate.

$\dot{\mathrm{E}} \mathrm{d}_{\mathrm{d}}=\sum\left(1-\frac{\mathrm{T}_{0}}{\mathrm{~T}}\right) \dot{\mathrm{Q}}-\dot{\mathrm{W}}_{\text {in }}+\sum_{\text {in }}$ me $-\sum_{\text {out }}$ me

The specific exergy (ei) equation in which kinetic and potential energies are neglected is given in Equation 2.11 .

$e_{i}=\left(h_{i}-h_{0}\right)-T_{0}\left(s_{i}-s_{0}\right)$

$\mathrm{h}_{0}$ and $\mathrm{s}_{0}$ show the specific enthalpy value and specific entropy value of the dead-state point, respectively.

Equations (2.12-2.19) required to calculate the exergy destruction rate and exergy efficiency for every component of the heat pump are dedicated below (Çengel \& Boles M. A., 2008; Chiasson, 2016; Dincer \& Kanoğlu, 2010):

\section{Compressor:}

$\dot{\mathrm{Ex}} \mathrm{d}_{\mathrm{d} \text { compressor }}=\dot{\mathrm{E}} \mathrm{x}_{\mathrm{d}, 1-2}=\dot{\mathrm{W}}_{\text {compressor,actual }}-\dot{\mathrm{m}}_{\mathrm{ref}}\left[\mathrm{h}_{2}-\mathrm{h}_{1}-\mathrm{T}_{0}\left(\mathrm{~s}_{2}-\mathrm{s}_{1}\right)\right]$

$\eta_{\text {ex,compressor }}=1-\frac{\dot{E}_{\mathrm{d}, \text { compressor }}}{\dot{\mathrm{W}}_{\text {compressor,actual }}}$

\section{Condenser:}

$\dot{\mathrm{E}} \mathrm{x}_{\mathrm{d}, \text { condenser }}=\dot{\mathrm{E}} \mathrm{x}_{\mathrm{d}, 2-3}=\dot{\mathrm{m}}_{\mathrm{ref}}\left[\mathrm{h}_{2}-\mathrm{h}_{3}-\mathrm{T}_{0}\left(\mathrm{~s}_{2}-\mathrm{s}_{3}\right)\right]-\dot{\mathrm{Q}}_{\text {condenser }}\left(1-\frac{\mathrm{T}_{0}}{\mathrm{~T}_{\mathrm{H}}}\right)$

$\eta_{\text {ex,condenser }}=1-\frac{\dot{\text { Ex }} \mathrm{d}_{\mathrm{d}, \text { condenser }}}{\dot{E}_{\mathrm{x}}-\dot{E x}_{3}}$

\section{Expansion valve:}

$\dot{\mathrm{Ex}} \mathrm{d}_{\mathrm{d}, \mathrm{AXV}}=\dot{\mathrm{Ex}} \mathrm{d}_{\mathrm{d}, 3-4}=\dot{\mathrm{m}}_{\mathrm{ref}}\left[\mathrm{h}_{3}-\mathrm{h}_{4}-\mathrm{T}_{0}\left(\mathrm{~s}_{3}-\mathrm{s}_{4}\right)\right]$

$\eta_{\mathrm{ex}, \mathrm{AXV}}=1-\frac{\dot{\mathrm{E}} \mathrm{x}_{\mathrm{d}, \mathrm{AXV}}}{\dot{\mathrm{Ex}} \mathrm{x}_{3}-\dot{\mathrm{Ex}}_{4}}$

\section{Evaporator:}

$\dot{\mathrm{Ex}} \mathrm{x}_{\mathrm{d}, \text { evaporator }}=\dot{\mathrm{E}} \mathrm{x}_{\mathrm{d}, 4-1}=\dot{\mathrm{m}}_{\mathrm{ref}}\left[\mathrm{h}_{4}-\mathrm{h}_{1}-\mathrm{T}_{0}\left(\mathrm{~s}_{4}-\mathrm{s}_{1}\right)\right]-\left[-\dot{\mathrm{Q}}_{\text {evaporator }}\left(1-\frac{\mathrm{T}_{0}}{\mathrm{~T}_{\mathrm{L}}}\right)\right]$
$\eta_{\text {ex,evaporatör }}=1-\frac{\dot{\mathrm{E} \mathrm{x}_{\mathrm{d}, \text { evaporator }}}}{\dot{\mathrm{Ex}}_{4}-\dot{\mathrm{E} \mathrm{x}_{1}}}$ 
After calculating the exergy destruction of components of the heat pump, the global exergy destruction rate $\left(\dot{\mathrm{E}} \mathrm{x}_{\mathrm{d}, \mathrm{sistem}}\right)$ and the exergy efficiency $\left(\eta_{\text {ex,sistem }}\right)$ of the heat pump can be calculated with Equation 2.20 and Equation 2.21, respectively.

$\dot{\mathrm{E}} \mathrm{x}_{\mathrm{d}, \text { sistem }}=\dot{\mathrm{E}} \mathrm{x}_{\mathrm{d}, 1-2}+\dot{\mathrm{E}} \mathrm{x}_{\mathrm{d}, 2-3}+\dot{\mathrm{E}} \mathrm{x}_{\mathrm{d}, 3-4}+\dot{\mathrm{E}} \mathrm{x}_{\mathrm{d}, 4-1}$
$\eta_{\text {ex }, \text { sistem }}=1-\frac{\dot{\mathrm{Ex}} \mathrm{x}_{\mathrm{d}, \text { sistem }}}{\dot{\mathrm{W}}_{\text {compressor,actual }}}$

The assumptions made for exergy analysis are given below:

- The dead-state pressure $\left(\mathrm{P}_{0}\right)$ was assumed to be $101.325 \mathrm{kPa}$.

- The dead state temperature $\left(\mathrm{T}_{0}\right)$ is assumed to be $298 \mathrm{~K}$.

\subsubsection{Environmental Analysis}

The equation of environmental analysis is given below (Equation 2.22) (Caliskan, 2017):

$\mathrm{x}_{\mathrm{CO}_{2}}=\mathrm{EM} \dot{\mathrm{W}}_{\text {compressor }} \mathrm{t}$

$\mathrm{x}_{\mathrm{CO}_{2}}, \mathrm{EM}, \mathrm{W}_{\text {compressor }}$ and $\mathrm{t}$ show greenhouse gas emission released in a certain period $\left(\mathrm{kgCO}_{2} / \mathrm{time}\right)$, emission value of the energy source option used in electricity generation $\left(\mathrm{kgCO}_{2} / \mathrm{kWh}\right)$, the power consumption of the compressor system $(\mathrm{kW})$ and operating time of system in a certain period (h/time), respectively.

\subsubsection{Enviro-economic Analysis}

The equation of enviro-economic analysis is given below (Equation 2.23) (Caliskan, 2017):

$\mathrm{C}_{\mathrm{CO}_{2}}=\mathrm{c}_{\mathrm{CO}_{2}} \mathrm{x}_{\mathrm{CO}_{2}}$

$\mathrm{x}_{\mathrm{CO}_{2}}$ is the value of environmental analysis $\left(\mathrm{kgCO}_{2} /\right.$ time $), \mathrm{c}_{\mathrm{CO}_{2}}$ is price of the $\mathrm{CO}_{2}$ emission $\left(\$ / \mathrm{kgCO}_{2}\right)$ and $\mathrm{C}_{\mathrm{CO}_{2}}$ is enviro-economic result (\$/time).

The acceptances made to perform environmental and enviro-economic analysis are dedicated in Table $\underline{3}$.

Table 3

Assumptions made for environmental and enviro- economic analysis

\begin{tabular}{ll}
\hline Heating capacity & $1 \mathrm{~kW}$ \\
\hline $\mathrm{t}$ & $12 \mathrm{~h} /$ day \\
\hline $\mathrm{EM}$ & $0.523 \mathrm{kgCO} / \mathrm{kWh}$ (Atilgan \& Azapagic, 2016) \\
\hline $\mathbf{c}_{\mathrm{CO}_{2}}$ & $14.5 \quad \$ /$ tonCO \\
\hline
\end{tabular}

\section{Results and Discussion}

In this investigation, the use of R450A refrigerant instead of R134a in low and medium-temperature heat pump systems has been investigated. The energy, exergy and environmental impact analysis of heat pump system were performed for R134a and its alternative R450A. 


\subsection{Results of Energy Analysis}

The energy analysis of the heat pump system has been made according to first law of thermodynamics. In the case of using R134a and R450A refrigerants in the heat pump system, mass flow rate, compressor energy consumption, cooling capacity and heating capacity are given in Figure 4.

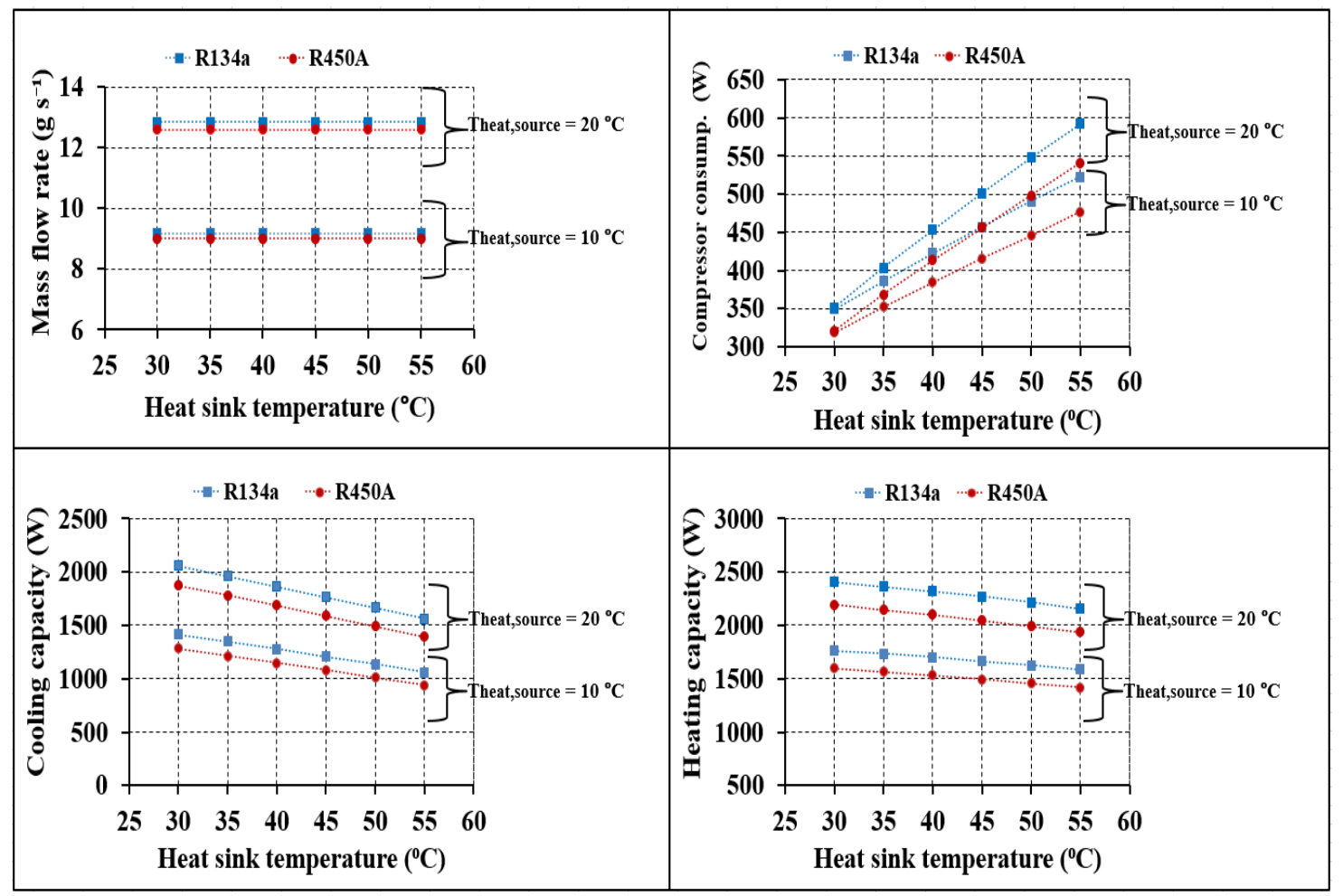

Figure 4. The mass flow rate, compressor energy consumption, cooling capacity and heating capacity of refrigerants

At $10{ }^{\circ} \mathrm{C}$ heat source temperature, the mass flow rate of $\mathrm{R} 134 \mathrm{a}$ and $\mathrm{R} 450 \mathrm{~A}$ is $9.18 \mathrm{~g} / \mathrm{s}$ and $9.01 \mathrm{~g} / \mathrm{s}$, respectively. At $20{ }^{\circ} \mathrm{C}$ heat source temperature, the mass flow rate of R134a and R450A is $12.85 \mathrm{~g} / \mathrm{s}$ and $12.59 \mathrm{~g} / \mathrm{s}$, respectively. As seen in Figure 4, R134a has a higher mass flow rate than R450A. This is an expected result. Because the suction line density of R134a is higher than R450A. Under ideal conditions, the condenser temperature does not influence the refrigerant mass flow rate.

Compressor energy consumption depends on the refrigerant mass flow rate and the specific compression work. Compressor energy consumption is one of the parameters affecting the performance coefficient (COP) of the heat pump system. As seen in Figure 4, the compressor energy consumption of R134a is higher than $\mathrm{R} 450$. At $10{ }^{\circ} \mathrm{C}$ heat source temperature, the compressor energy consumption of $\mathrm{R} 134 \mathrm{a}$ varies between $348.90 \mathrm{~W}$ and $522.71 \mathrm{~W}$, while the compressor energy consumption of R450A varies between $318.66 \mathrm{~W}$ and $476.86 \mathrm{~W}$.

The cooling capacity of the refrigerants relies on the refrigerant mass flow rate and the cooling effect (evaporator enthalpy difference). Figure 4 clearly shows that R134a has a higher cooling capacity than R450A. Because R134a has both a cooling effect (evaporator enthalpy difference) and a mass flow rate higher than $\mathrm{R} 450 \mathrm{~A}$. At $10{ }^{\circ} \mathrm{C}$ heat source temperature, the cooling capacity of $\mathrm{R} 134 \mathrm{a}$ varies between $1414.70 \mathrm{~W}$ and $1062.58 \mathrm{~W}$, while the cooling capacity of R450A varies between $1281.30 \mathrm{~W}$ and $940.75 \mathrm{~W}$.

The heating capacity of the refrigerants relies on the refrigerant mass flow rate and the heating effect (condenser enthalpy difference). As seen in Figure 4, R134a has a higher heating capacity than R450A. Because $\mathrm{R} 134 \mathrm{a}$ of the heating effect (condenser enthalpy difference) and mass flow rate higher than R450A. At $10{ }^{\circ} \mathrm{C}$ 
heat source temperature, the heating capacity of R134a varies between $1763.60 \mathrm{~W}$ and $1585.29 \mathrm{~W}$, while the heating capacity of R450A varies between $1599.95 \mathrm{~W}$ and $1417.61 \mathrm{~W}$.

The comparison of R134a and R450A's COP values is given in Figure 5. As the heat sink temperature increases, the COP value of both refrigerants decreases. As the heat sink temperature increases, the COP value of both refrigerants decreases. Because, when the heat sink temperature increases, the heating capacity of refrigerants diminishes, and compressor consumption of refrigerants rises. When we examine the COP values of refrigerants, it is seen that they are almost similar.

For example, at $10{ }^{\circ} \mathrm{C}$ heat source temperature and $30{ }^{\circ} \mathrm{C}, 35{ }^{\circ} \mathrm{C}, 40{ }^{\circ} \mathrm{C} 45{ }^{\circ} \mathrm{C}, 50{ }^{\circ} \mathrm{C}$ and $55{ }^{\circ} \mathrm{C}$ heat sink temperatures, the COP value of $\mathrm{R} 134 \mathrm{a}$ is $5.05,4.49,4.03$, 3.64, 3.32 and 3.03, respectively. Under the same conditions, the COP value of R450A is 5.02, 4.45, 3.99, 3.60, 3.27 and 2.97, respectively.

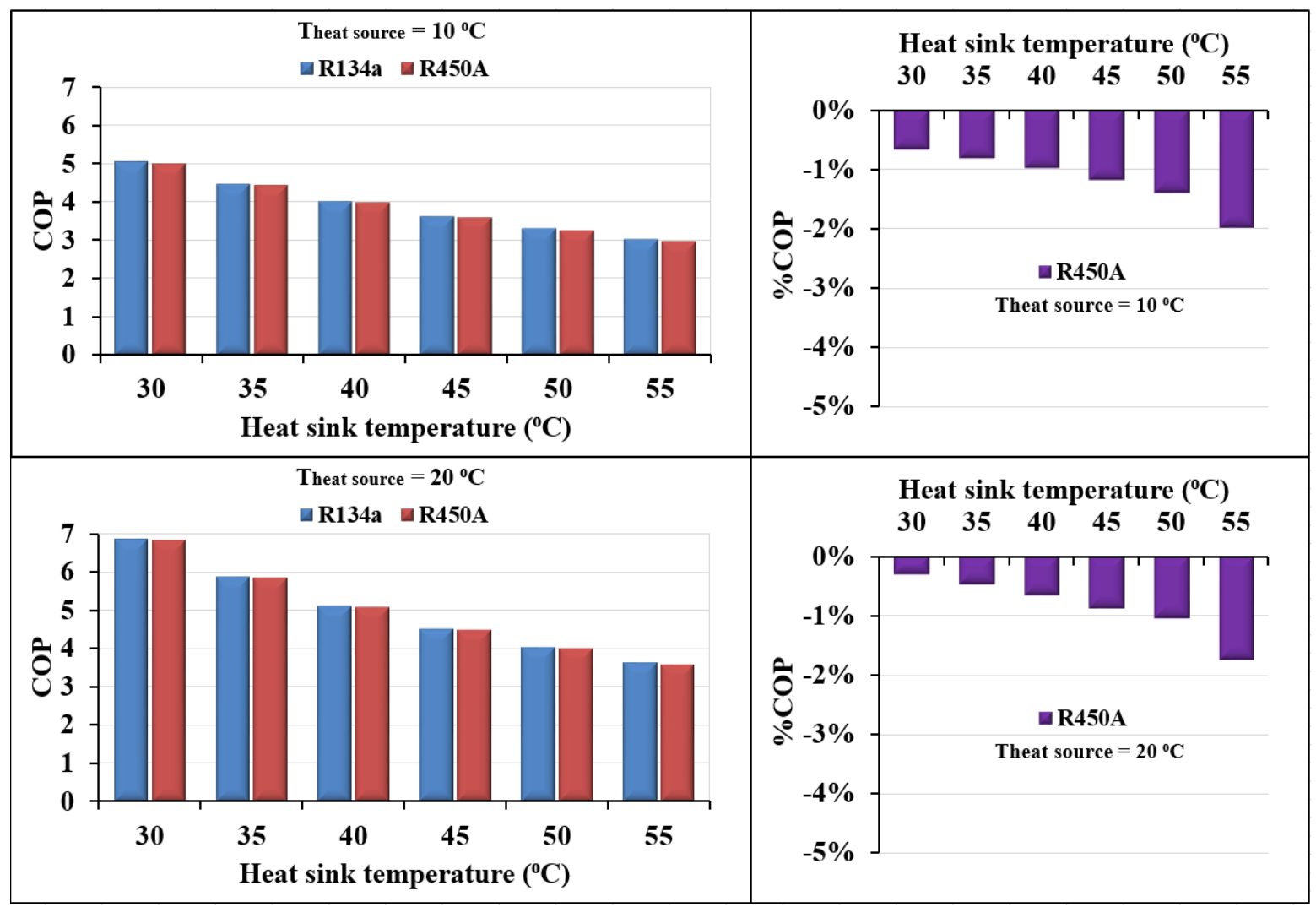

Figure 5. The comparison of R134a and R450A's the COP values

\subsection{Results of Exergy Analysis}

The exergy analysis of heat pump system has been made according to second law of thermodynamics. The total exergy destruction rate and exergy efficiency of the heat pump system are given in Figure 6. 


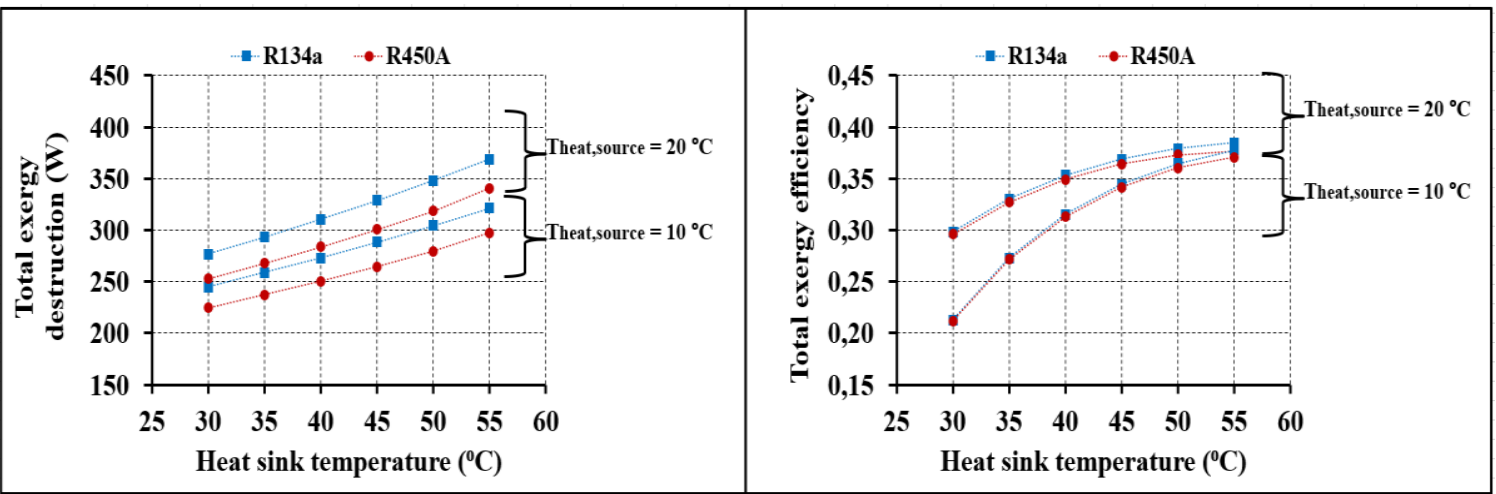

Figure 6. Total exergy performance of heat pump system

At $10{ }^{\circ} \mathrm{C}$ heat source temperature and $30{ }^{\circ} \mathrm{C}, 35{ }^{\circ} \mathrm{C}, 40{ }^{\circ} \mathrm{C} 45{ }^{\circ} \mathrm{C}, 50{ }^{\circ} \mathrm{C}$ and $55{ }^{\circ} \mathrm{C}$ heat sink temperatures, the exergy destruction rate of R134a is $244.87 \mathrm{~W}, 258.68 \mathrm{~W}, 273.14 \mathrm{~W}, 288.36 \mathrm{~W}, 304.40 \mathrm{~W}$ and $321.49 \mathrm{~W}$, respectively. Under the same conditions, the exergy destruction rate of R450A is $224.39 \mathrm{~W}, 237.07 \mathrm{~W}$, $250.38 \mathrm{~W}, 264.51 \mathrm{~W}, 279.36 \mathrm{~W}$ and $297.42 \mathrm{~W}$, respectively. As heat sink temperature rises, the total exergy destruction rate increases. At $10{ }^{\circ} \mathrm{C}$ heat source temperature and $30{ }^{\circ} \mathrm{C}, 35{ }^{\circ} \mathrm{C}, 40{ }^{\circ} \mathrm{C} 45{ }^{\circ} \mathrm{C}, 50{ }^{\circ} \mathrm{C}$ and $55{ }^{\circ} \mathrm{C}$ heat sink temperatures, the total exergy efficiency of R134a is $0.298,0.330,0.353,0.369,0.379$ and 0.385 , respectively. Under the same conditions, total exergy efficiency of R450A is $0.296,0.327,0.349,0.364$, 0.373 and 0.376 , respectively. The total exergy efficiency increases when heat sink temperature rises. But, total exergy efficiency after $45{ }^{\circ} \mathrm{C}$ heat sink temperature slightly rising. The exergy results of the second law for the entire heat pump system show that R450A behaves similarly to R134a.

To examine the exergy analysis of the heat pump system in detail, the exergy performance of the heat pump components has been made. The exergy destruction rates and exergy efficiencies of components are given in Table 4. When we examine Table 4, it is clear that the system components of R134a and R450A are generally similar. 
Table 4

Exergy destruction rates and exergy efficiencies of components

\begin{tabular}{|c|c|c|c|c|c|c|c|c|c|}
\hline \multirow{2}{*}{$\begin{array}{l}\mathbf{T}_{\text {heat,sink }} \\
\left({ }^{\circ} \mathbf{C}\right)\end{array}$} & \multirow[t]{2}{*}{ Refrigerant } & \multicolumn{2}{|c|}{ Compressor } & \multicolumn{2}{|c|}{ Condenser } & \multicolumn{2}{|c|}{ Evaporator } & \multicolumn{2}{|c|}{ Expansion valve } \\
\hline & & $\begin{array}{c}\text { Exergy } \\
\text { destruction } \\
\text { rate }(W)\end{array}$ & $\begin{array}{c}\text { Exergy } \\
\text { efficiency } \\
(-)\end{array}$ & $\begin{array}{c}\text { Exergy } \\
\text { destruction } \\
\text { rate }(W)\end{array}$ & $\begin{array}{c}\text { Exergy } \\
\text { efficiency } \\
(-)\end{array}$ & $\begin{array}{c}\text { Exergy } \\
\text { destruction } \\
\text { rate }(W)\end{array}$ & $\begin{array}{c}\text { Exergy } \\
\text { efficiency } \\
(-)\end{array}$ & $\begin{array}{c}\text { Exergy } \\
\text { destruction } \\
\text { rate }(W)\end{array}$ & $\begin{array}{c}\text { Exergy } \\
\text { efficiency } \\
(-)\end{array}$ \\
\hline \multicolumn{10}{|c|}{$\mathbf{T}_{\text {heat,source }}=10^{\circ} \mathrm{C}$} \\
\hline 30 & $\mathrm{R} 134 \mathrm{a}$ & 95.26 & 0.73 & 60.54 & 0.32 & 54.03 & 0.58 & 35.04 & 0.91 \\
\hline 35 & R134a & 103.75 & 0.73 & 58.47 & 0.49 & 51.56 & 0.58 & 44.89 & 0.89 \\
\hline 40 & $\mathrm{R} 134 \mathrm{a}$ & 111.42 & 0.74 & 56.62 & 0.59 & 48.98 & 0.58 & 56.12 & 0.86 \\
\hline 45 & R134a & 118.53 & 0.74 & 54.55 & 0.66 & 46.29 & 0.58 & 68.98 & 0.83 \\
\hline 50 & R134a & 125.10 & 0.74 & 52.85 & 0.70 & 43.51 & 0.58 & 82.95 & 0.80 \\
\hline 55 & R134a & 131.40 & 0.75 & 50.81 & 0.74 & 40.45 & 0.58 & 98.82 & 0.77 \\
\hline 30 & R450A & 88.10 & 0.72 & 52.50 & 0.33 & 49.35 & 0.58 & 34.44 & 0.90 \\
\hline 35 & R450A & 95.89 & 0.73 & 50.26 & 0.50 & 46.73 & 0.58 & 44.19 & 0.88 \\
\hline 40 & $\mathrm{R} 450 \mathrm{~A}$ & 102.88 & 0.73 & 48.22 & 0.60 & 44.07 & 0.58 & 55.20 & 0.85 \\
\hline 45 & R450A & 109.32 & 0.74 & 46.35 & 0.67 & 41.38 & 0.58 & 67.45 & 0.82 \\
\hline 50 & R450A & 115.50 & 0.74 & 44.14 & 0.72 & 38.63 & 0.58 & 81.09 & 0.78 \\
\hline 55 & R450A & 121.68 & 0.74 & 43.61 & 0.75 & 35.83 & 0.58 & 96.30 & 0.75 \\
\hline \multicolumn{10}{|c|}{$T_{\text {heat,source }}=20^{\circ} \mathrm{C}$} \\
\hline 30 & R134a & 96.95 & 0.72 & 79.75 & 0.33 & 73.72 & 0.32 & 26.44 & 0.95 \\
\hline 35 & $\mathrm{R} 134 \mathrm{a}$ & 109.22 & 0.73 & 76.94 & 0.50 & 70.30 & 0.32 & 36.79 & 0.93 \\
\hline 40 & R134a & 120.71 & 0.73 & 74.03 & 0.60 & 66.67 & 0.32 & 49.05 & 0.91 \\
\hline 45 & R134a & 131.06 & 0.74 & 71.19 & 0.67 & 63.21 & 0.32 & 63.23 & 0.89 \\
\hline 50 & $\mathrm{R} 134 \mathrm{a}$ & 141.03 & 0.74 & 68.70 & 0.71 & 59.53 & 0.32 & 78.94 & 0.87 \\
\hline 55 & R134a & 150.22 & 0.75 & 65.76 & 0.75 & 55.78 & 0.32 & 96.95 & 0.84 \\
\hline 30 & $\mathrm{R} 450 \mathrm{~A}$ & 89.34 & 0.72 & 70.20 & 0.34 & 67.10 & 0.32 & 26.35 & 0.95 \\
\hline 35 & R450A & 100.60 & 0.73 & 67.27 & 0.51 & 63.68 & 0.32 & 36.45 & 0.93 \\
\hline 40 & R450A & 111.11 & 0.73 & 64.24 & 0.61 & 60.22 & 0.32 & 48.24 & 0.90 \\
\hline 45 & R450A & 120.87 & 0.74 & 61.42 & 0.68 & 56.65 & 0.32 & 61.75 & 0.88 \\
\hline 50 & $\mathrm{R} 450 \mathrm{~A}$ & 129.88 & 0.74 & 58.47 & 0.72 & 53.20 & 0.32 & 76.94 & 0.85 \\
\hline 55 & R450A & 138.89 & 0.74 & 57.76 & 0.75 & 49.44 & 0.32 & 94.48 & 0.82 \\
\hline
\end{tabular}

Exergy destruction occurred mostly in the compressor under all operating conditions for refrigerants. At low heat sink temperatures, the least exergy destruction occurs in the expansion valve, while the lowest exergy destruction occurs in the evaporator at high heat sink temperatures. This is clearly seen in the exergy flow diagrams are given in Figure 7 and Figure 8.

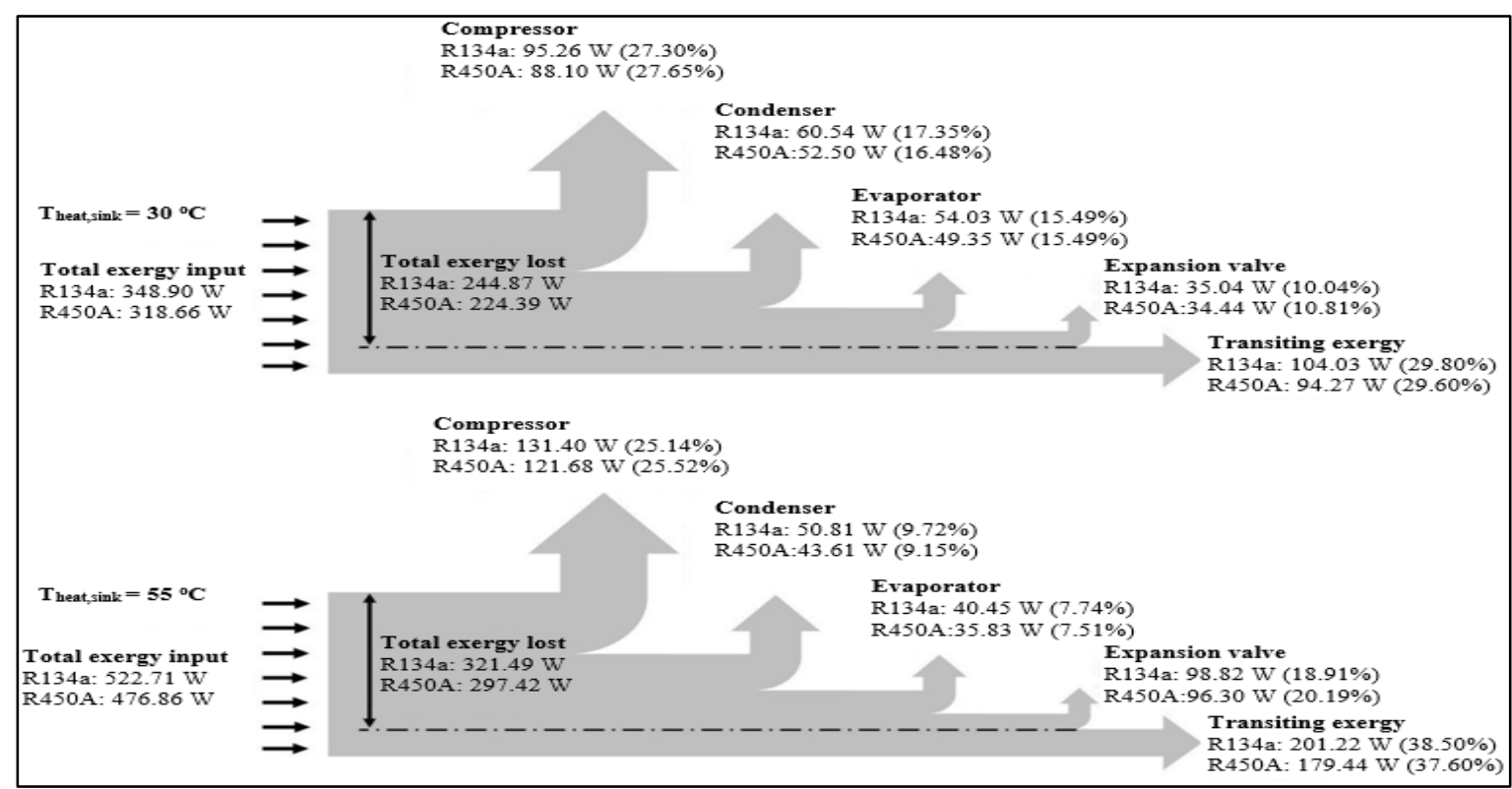

Figure 7. Exergy flow diagram for $\mathrm{T}_{\text {heat,source }}=10^{\circ} \mathrm{C}$ 


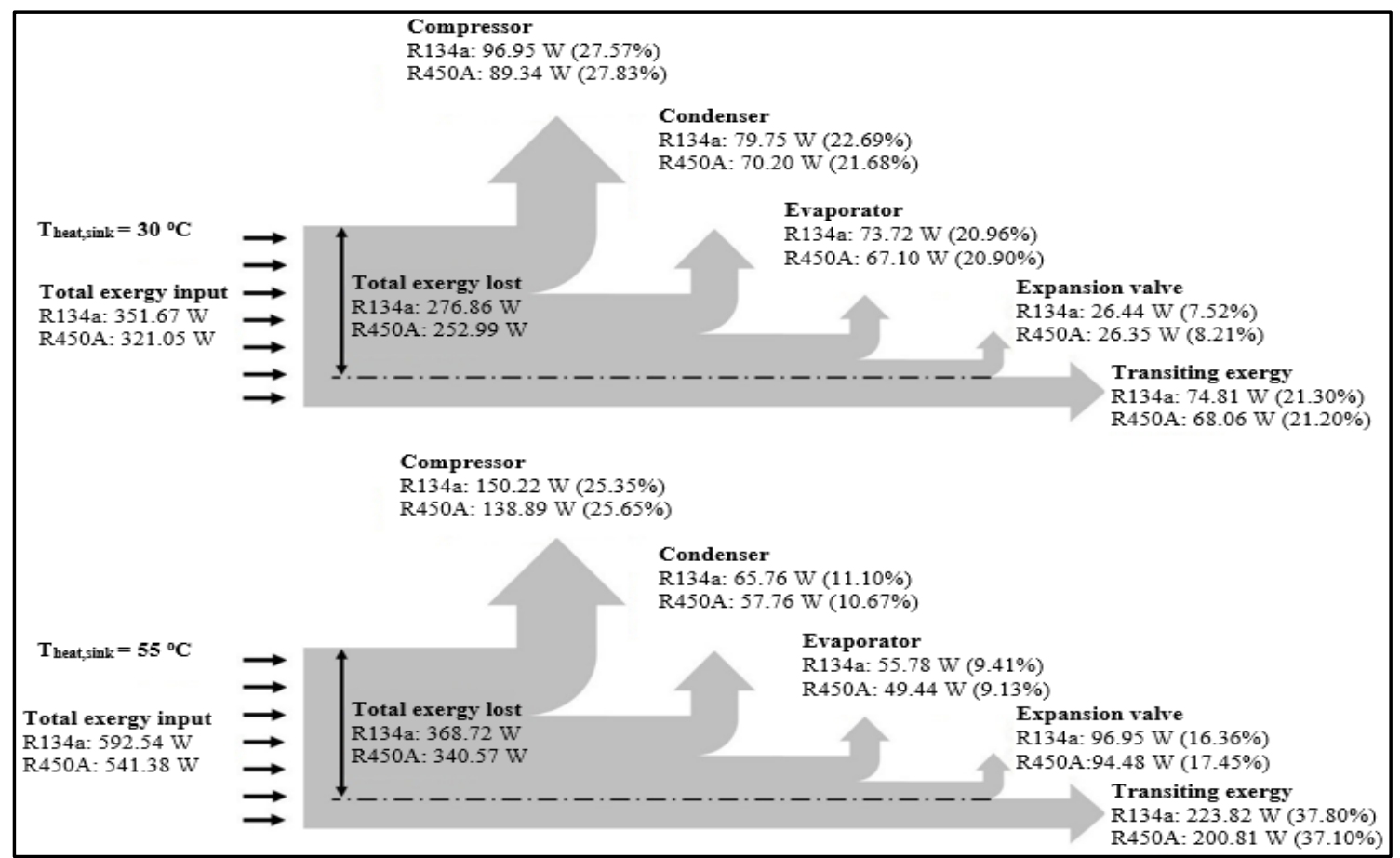

Figure 8. Exergy flow diagram for $\mathrm{T}_{\text {heat,source }}=20^{\circ} \mathrm{C}$

\subsection{Results of Environmental Analysis}

The environmental analysis gives the emission value $\left(\mathrm{kgCO}_{2} / \mathrm{time}\right)$ in a certain period (such as hour, day, month, year) depending on the energy consumption of a system and the energy source option used (traditional energy sources or renewable energy sources).

Environmental analysis results are given in Table 5. When we examine the environmental analysis results, it is seen that there are very small values. Because the analyzes have been made for a very small-scale heat pump system. The environmental analysis results of R450A are slightly higher than R134a.

Table 5

Environmental analysis results $\left(\mathrm{kgCO}_{2} /\right.$ day $)$

\begin{tabular}{lccc}
\hline $\mathbf{T}_{\text {heat,source }}\left({ }^{\mathbf{C}} \mathbf{C}\right)$ & $\mathbf{T}_{\text {heat,sink }}\left({ }^{\mathbf{}} \mathbf{C}\right)$ & $\mathbf{R 1 3 4 a}$ & $\mathbf{R 4 5 0 A}$ \\
\hline $\mathbf{1 0}{ }^{\mathbf{}} \mathbf{C}$ & 30 & 1.24 & 1.25 \\
& 35 & 1.40 & 1.41 \\
\cline { 2 - 4 } & 40 & 1.56 & 1.57 \\
\cline { 2 - 4 } & 45 & 1.72 & 1.74 \\
& 50 & 1.89 & 1.92 \\
\hline $\mathbf{2 0}^{\mathbf{0}} \mathbf{C}$ & 55 & 2.07 & 2.11 \\
& 30 & 0.92 & 0.92 \\
& 35 & 1.07 & 1.08 \\
& 40 & 1.23 & 1.24 \\
& 45 & 1.39 & 1.40 \\
\cline { 2 - 4 } & 50 & 1.55 & 1.57 \\
\cline { 2 - 4 } & 55 & 1.72 & 1.75
\end{tabular}

\subsection{Results of Enviro-economic Analysis}

The enviro-economic analysis relies on environmental analysis and greenhouse gas emission price. Carbon pricing is one of the effective methods used to reduce greenhouse gases. Therefore, enviro-economic analysis is used to evaluate a system in terms of environmental economic (carbon pricing). 
The enviro-economic analysis results are given in Table 6. The enviro-economic analysis results are in very small values similar to environmental analysis results. The enviro-economic analysis results of R450A are almost the same as R134a.

Table 6

Enviro-economic analysis results (\$/day)

\begin{tabular}{|c|c|c|c|}
\hline $\mathbf{T}_{\text {heat,source }}\left({ }^{\mathbf{0}} \mathbf{C}\right)$ & $\mathbf{T}_{\text {heat,sink }}\left({ }^{\circ} \mathrm{C}\right)$ & R134a & R450A \\
\hline \multirow{6}{*}{$10^{\circ} \mathrm{C}$} & 30 & 0.018 & 0.018 \\
\hline & 35 & 0.020 & 0.020 \\
\hline & 40 & 0.023 & 0.023 \\
\hline & 45 & 0.025 & 0.025 \\
\hline & 50 & 0.027 & 0.028 \\
\hline & 55 & 0.030 & 0.031 \\
\hline \multirow{6}{*}{$20^{\circ} \mathrm{C}$} & 30 & 0.013 & 0.013 \\
\hline & 35 & 0.016 & 0.016 \\
\hline & 40 & 0.018 & 0.018 \\
\hline & 45 & 0.020 & 0.020 \\
\hline & 50 & 0.023 & 0.023 \\
\hline & 55 & 0.025 & 0.025 \\
\hline
\end{tabular}

\section{Conclusion}

In this study, the evaluation of the use R450A and R134a in low and medium-temperature heat pump systems has been investigated. The energy, exergy, environmental and enviro-economic analyzes of the heat pump have been performed for R134a and R450A. The R450A's mass flow rate is lower than R134a. Because the density of R450A in the heat pump suction line is lower than R134a. The compressor power consumption of R134a is higher than R450A. Despite the cooling and heating capacity of R134a are higher than $\mathrm{R} 450 \mathrm{~A}$, the heating COP value of R134a has slightly higher than R450A. The exergy results of the second law for the entire heat pump system show that R450A behaves similarly to R134a. Exergy destruction occurred mostly in the compressor under all operating conditions for refrigerants. At low heat sink temperatures, the least exergy destruction occurs in the expansion valve, while the lowest exergy destruction occurs in the evaporator at high heat sink temperatures. The environmental analysis results of R450A are slightly higher than R134a. The enviro-economic analysis results of R450A are almost the same as R134a. As a result, R450A can be used as an alternative refrigerant in heat pump systems operating with R134a according to energy, exergy, environmental and environmental-economic analysis investigations.

\section{Author Contributions}

Ragip Y1ldirım: Designed and performed the study and wrote the paper.

\section{Conflicts of Interest}

The authors declare no conflict of interest.

\section{References}

Arora, P., Seshadri, G., \& Tyagi, A. K. (2018). Fourth-generation refrigerant: HFO 1234yf. Current Science, 115(8), 1497-1503. https://doi.org/10.18520/cs/v115/i8/1497-1503

Atilgan, B., \& Azapagic, A. (2016). Assessing the Environmental Sustainability of Electricity Generation in Turkey on a Life Cycle Basis. Energies, 9(1), 31. https://doi.org/10.3390/en9010031

Caliskan, H. (2017). Energy, exergy, environmental, enviroeconomic, exergoenvironmental (EXEN) and exergoenviroeconomic (EXENEC) analyses of solar collectors. In Renewable and Sustainable Energy Reviews (Vol. 69, pp. 488-492). Elsevier Ltd. https://doi.org/10.1016/j.rser.2016.11.203

Calm, J. M. (2008). The next generation of refrigerants - Historical review, considerations, and outlook. In 
International Journal of Refrigeration (Vol. 31, Issue 7, pp. 1123-1133). Elsevier. https://doi.org/10.1016/j.ijrefrig.2008.01.013

Çengel, Y. A., \& Boles M. A. (2008). Termodinamik: mühendislik yaklaşımıyla (A. Pınarbaşı (ed.)). İzmir Güven Kitabevi.

Chiasson, A. D. (2016). Geothermal Heat Pump and Heat Engine Systems. In Geothermal Heat Pump and Heat Engine Systems. John Wiley \& Sons, Ltd. https://doi.org/10.1002/9781118961957

Ciconkov, R. (2018). Refrigerants: There is still no vision for sustainable solutions. In International Journal of Refrigeration (Vol. 86, pp. 441-448). Elsevier Ltd. https://doi.org/10.1016/j.ijrefrig.2017.12.006

Devecioğlu, A. G., \& Oruç, V. (2018). A comparative energetic analysis for some low-GWP refrigerants as $\mathrm{R} 134 \mathrm{a}$ replacements in various vapor compression refrigeration systems. J. of Thermal Science and Technology, 38(2), 51-61. https://dergipark.org.tr/en/pub/isibted/780446

Dincer, İ., \& Kanoğlu, M. (2010). Refrigeration systems and applications (Second). Wiley. https://doi.org/10.1002/9780470661093

Gatarić, P., \& Lorbek, L. (2021). Evaluating R450A as a drop-in replacement for R134a in household heat pump tumble dryers. International Journal of Refrigeration. https://doi.org/10.1016/j.ijrefrig.2021.03.020

Gill, J., Singh, J., Ohunakin, O. S., \& Adelekan, D. S. (2019). Exergy analysis of vapor compression refrigeration system using R450A as a replacement of R134a. Journal of Thermal Analysis and Calorimetry, 136(2), 857-872. https://doi.org/10.1007/s10973-018-7675-z

Heredia-Aricapa, Y., Belman-Flores, J. M., Mota-Babiloni, A., Serrano-Arellano, J., \& García-Pabón, J. J. (2020). Overview of low GWP mixtures for the replacement of HFC refrigerants: R134a, R404A and R410A. In International Journal of Refrigeration (Vol. 111, pp. 113-123). Elsevier Ltd. https://doi.org/10.1016/j.ijrefrig.2019.11.012

Jiang, J., Hu, B., Wang, R. Z., Liu, H., Zhang, Z., \& Li, H. (2021). Theoretical Performance Assessment of Low-GWP Refrigerant R1233zd(E) Applied in High Temperature Heat Pump System. International Journal of Refrigeration. https://doi.org/10.1016/j.ijrefrig.2021.03.026

Kumaş, K., \& Akyüz, A. (2020). Performance Analysis of R450A Refrigerant in Vapor Compression Cooling System for Sustainable Environment. Academia Journal of Nature and Human Sciences, 6(1), 57-71. https://dergipark.org.tr/tr/pub/adibd

Llopis, R., Sánchez, D., Cabello, R., Catalán-Gil, J., \& Nebot-Andrés, L. (2017). Experimental analysis of R450A and R-513A as replacements of R-134a and R-507A in a medium temperature commercial refrigeration system. International Journal of Refrigeration, 84, 52-66. https://doi.org/10.1016/j.ijrefrig.2017.08.022

Mateu-Royo, C., Arpagaus, C., Mota-Babiloni, A., Navarro-Esbrí, J., \& Bertsch, S. S. (2021). Advanced high temperature heat pump configurations using low GWP refrigerants for industrial waste heat recovery: A comprehensive study. Energy Conversion and Management, 229, 113752. https://doi.org/10.1016/j.enconman.2020.113752

Velasco, F. J. S., Illán-Gómez, F., \& García-Cascales, J. R. (2021). Energy efficiency evaluation of the use of R513A as a drop-in replacement for R134a in a water chiller with a minichannel condenser for airconditioning applications. Applied Thermal Engineering, 182, 115915. https://doi.org/10.1016/j.applthermaleng.2020.115915

Yang, Z., Feng, B., Ma, H., Zhang, L., Duan, C., Liu, B., Zhang, Y., Chen, S., \& Yang, Z. (2021). Analysis of lower GWP and flammable alternative refrigerants. International Journal of Refrigeration, 126, 12 22. https://doi.org/10.1016/j.ijrefrig.2021.01.022

Yildirim, R., \& Yildiz, A. (2020a). Evaluation of performance of hfc-r134a/hfo-1234yf binary mixtures used as refrigerant in a heat pump system. El-Cezeri Journal of Science and Engineering, 7(3), 1440-1449. https://doi.org/10.31202/ecjse.734445

Yildirim, R., \& Yildiz, A. (2020b). Energy, environmental and enviroeconomic analysis of the use $\mathrm{R} 134 \mathrm{a} / \mathrm{R} 1234 \mathrm{yf}$ (10/90) as replace to R134a in a vapor compression cooling system. International Journal of Energy Applications and Technologies, 7(4), 101-106. https://doi.org/10.31593/ijeat.769962

Zhang, J., Zhang, H. H., He, Y. L., \& Tao, W. Q. (2016). A comprehensive review on advances and applications of industrial heat pumps based on the practices in China. In Applied Energy (Vol. 178, pp. 800-825). Elsevier Ltd. https://doi.org/10.1016/j.apenergy.2016.06.049

Zilio, C., Brown, J. S., Schiochet, G., \& Cavallini, A. (2011). The refrigerant R1234yf in air conditioning systems. Energy, 36(10), 6110-6120. https://doi.org/10.1016/j.energy.2011.08.002 